\title{
The Religion of Creativity: A Destructive Justice
}

\author{
DANIELE GOLDONI \\ goldoni@unive.it \\ Ca' Foscari University of Venice
}

\begin{abstract}
The modern economy has developed within the domain of a justified power, by purporting to achieve a kind of social justice (fairness). In the current knowledge-creating economy, socalled "merit" realizes itself only in a hard competitive context: fairness is impossible. The myth of creativity exercises a seductive power, by promising a lifestyle without (need of) justification. An interpretation of Benjamin's Capitalism as Religion (1921) and of Nietzsche's texts (The Joyful Wisdom, Thus Spoke Zarathustra, The Genealogy of Morals) may throw light on this lifestyle, as well on the philosophical and political weakness of some resistance movements of the Seventies. The proposal is to resist by deactivating the ambition to be creative.
\end{abstract}

\section{Capitalism and (in)justice}

The modern economy was born and has developed within the domain of a justified political power. This justification was political in so far as this use of the economy was legitimate, as European monarchies are. This weaving between justification and the right of the state did not cease even when the economy became political in so far as it served the nation, so that legitimacy came to be replaced by legislative power and legality in the name of the people. Adam Smith conceived political economy as a branch of moral philosophy: the economy serves the nation in a way that should achieve a kind of social and moral justice (fairness). The genealogy of this interweaving of economy, politics and morality goes back to the "divine economy" of Christian Trinitarian theology (Agamben, 2011).

As late as the mid-Nineteenth century, John Stuart Mill conceived political economy as a branch of the moral and social sciences (Mill, [1848] 2010). But in the Twentieth century "economics" rather became a branch of the computational and statistic sciences. The concept of economic "equilibrium" has replaced the principle of fairness. Nowadays the new capitalism insists on "innovation" and "creativity" more than on equilibrium. Even though economics has foregone the idea of fairness, current capitalism still presents a principle of justification: merit. This allegedly constitutes a different sort of justice - this, too, with a Christian theological genealogy: to each is given according to his own merits. But how can merit be measured? One might consider its effects. These could be evaluated, for instance, in relation to the common utility of any "creative" innovation. Or - as is usually the case in the current economy - creativity is evaluated with respect to its market success. The market is highly dependent on financial power; innovations do not necessarily have a direct impact on the lives of international investors; what consumers want is highly conditioned, even "schematized", by industries, including the "cultural and creative industries" (Adorno, 
[1947] 1998; Débord, 1967; Foucault, [1978-1979] 2004; Hesmondhalgh, 2013): therefore the evaluation of the "merit" of an innovation may be very weakly related to common utility, or not at all. So-called merit realizes itself only in a hard competitive context: few succeed, while most people - necessarily - fail. Failure results in underemployment or unemployment, social exclusion, precarious and often undignified ways of life (Fumagalli, 2007). Fairness is impossible. How can all this be tolerated?

One answer is: economic power has a huge force of blackmail (T.I.N.A = There Is No Alternative). But while this is true, it cannot explain why so many people are fascinated by the myth of creativity. Its seductive power consists in the promise of a way of life that abandons the traditional idea of justice as fairness, and ventures into a lifestyle without (need of) justification - a reckless life even, which entails many contradictions: an extreme freedom, never experimented before.

This development seems to have put an end to the effects of the genealogy of the Christian religion of the economy. Or is it, instead, a further development of the "parasitizing" of this religion by capitalism?

Capitalism has developed as a parasite of Christianity in the West (this must be shown no just in the case of Calvinism, but in the other orthodox Christian churches), until it reached the point where Christianity's history is essentially that of its parasite - that is to say, of capitalism (Benjamin, [1921] 1996).

\section{The religion of a desperate guilt/debt}

Benjamin claims that capitalism is a religion in so far as it:

serves essentially to allay the same anxieties, torments, and disturbances to which the so-called religions offered answers... In the first place, capitalism is a purely cultic religion, perhaps the most extreme that ever existed. In capitalism, things have no meaning only in their relationship to the cult; capitalism has no specific body of dogma, no theology... (Benjamin, [1921] 1996).

Walter Benjamin wrote these words in 1921: almost a century ago. However, they fit well with some features of the new capitalism:

[...] This concretization of cult is connected with a second feature of capitalism: the permanence of the cult. Capitalism is the celebration of the cult sans [t]reve et sans merci... There are no "weekdays." There is no day that is not a feast day, in the terrible sense that all its sacred pomp is unfolded before us; each day commands the utter fealty of each worshipper (Benjamin, [1921] 1996).

(Steiner 1998: 157) compellingly suggests that we read trêve instead of rêve. See also Salzani 2013, p. 15). These words describe exactly the ways in which now - in the days once devoted to rest and sacred celebrations - consumption, entertainment and social relations are being celebrated in shopping centres as ritual aspects of the new cult.

And third, the cult makes guilt pervasive. Capitalism is probably the first instance of a cult that creates guilt, not atonement. In this respect, this religious system is caught up in the headlong rush of a larger movement. A vast sense guilt that is unable to find relief seizes on the cult, not to atone for this guilt but to make it universal, to hammer it into the conscious mind... (Benjamin, 1921] 1996). 
Some scholars have already discussed this text, especially with reference to the recent and still ongoing debt crisis in European states, sharing its interpretation of capitalism as a religion that produces at the same time debt and guilt (Hamacher, 2003; Löwy, 2006; Steiner, 2006; Stimilli, 2011; 2015; Salzani, 2013; Agamben, 2013); the idea of capitalism as a system of indebtedness is also to be found in Lazzarato (2011). Benjamin himself notes the ambiguity of the German word Schuld:

Schuld (consider the demonic ambiguity of this word) (Benjamin, [1921] 1996).

Benjamin does not explain why capitalism produces at the same time debt and guilt. He says that capitalism has developed as a "parasite" of Christianity. Original sin becomes the original economic debt. This interpretation fits with Calvinism, since there is no remission of guilt, if not by predestination. The "profession", according Max Weber (Weber, [1905] 2014), is an act of faith that compels one to constantly produce profit throughout one's life, since it is never possible to know whether and when one has been forgiven by God. Interestingly, however, Benjamin claims that:

this must be shown not just in the case of Calvinism, but in the other orthodox Christian churches (Benjamin, 1921] 1996).

I suppose that Benjamin sees also in the "orthodox Christian churches" a sort of administration of original sin, which - according their main traditional interpretations never ceases to make humans guilty: so that people need churches and priests for salvation, and, in the Catholicism of the Counter Reformation, need the sacraments given by priests ex opere operato. Human existence has a debt that can be redeemed only by God, and which will be completely forgiven (or confirmed) only in the Final Judgment. Therefore, the present is always guilty and indebted to the future life - even after death. I would argue that capitalism denies the self-sufficiency of existence, denies the full enjoyment of life in the present. Present and past have no value in themselves: they must be redeemed by the future. But, according Benjamin, capitalism in fact offers no redemption at all:

A vast sense guilt that is unable to find relief seizes on the cult, not to atone for this guilt but to make it universal, to hammer it into the conscious mind, so as once and for all to include God in the system of guilt and thereby awaken in Him an interest in the process of atonement... The nature of the religious movement which is capitalism entails endurance right to the end, to the point where God, too, finally takes on the entire burden of guilt, to the point where the universe has been taken over by that despair which is actually its secret hope. Capitalism is entirely without precedent, in that it is a religion which offers not the reform of existence but its complete destruction. It is the expansion of despair, until despair becomes a religious state of the world in the hope that this will lead to salvation (Benjamin, [1921] 1996).

Religion continues to drag men into the despair of a God who is desperate because of a guilt that he can no longer redeem, since he has taken the burden of it upon himself. It is impossible to cease hoping (in an end to guilt), but, through this hope, people go deeper and deeper into despair. Hope in salvation coincides with despair: such is the infernal circle of this religion. 


\section{The law and justice of the creator}

In this text Benjamin makes some references to Nietzsche's superman as the first to recognize the religion of capitalism and begin to bring it to fulfilment (Benjamin, [1921] 1996).

The experience of 'despair' is also mentioned in relation to Nietzsche:

This passage of the planet "Human" through the house of despair in the absolute loneliness of his trajectory is the ethos that Nietzsche defined (Benjamin, [1921] 1996).

The "absolute loneliness" of the "trajectory" sounds as a reference to The Joyful Wisdom:

We have left the land and have gone aboard ship! We have broken down the bridge behind us - nay, more, the land behind us!... Do we not stray, as through infinite nothingness? Does not empty space breathe upon us? Has it not become colder? Dose not night come on continually, darker and darker? (Nietzsche, [1882] 1924, §§ 124-125)

The passage of The Joyful Wisdom is the one in which a 'madman' reveals that humans have killed God. The revelation of the murder happens at the market! In Benjamin's text on capitalism, God's act of taking on the burden of guilt recalls the kenosis of Trinitarian theology, but also brings to mind a passage from Thus Spoke Zarathustra:

Thus spoke the devil to me, once on a time: "Even God has his hell: it is his love for man."

And lately, did I hear him say these words: "God is dead: of his pity for man has God died."- (Nietzsche, [1885] 2010, II, 3: 73)

Unlike Nietzsche, Benjamin points out that God is not dead: only his transcendence has come to at an end. According Benjamin, the superman recognizes the religion of capitalism, but only begins its fulfilment. He doesn't yet reveal its God.

Its fourth feature is that its God must be hidden from it and may be addressed only when his guilt is at its zenith. The cult is celebrated before an immature deity; every idea, every conception of it offends against the secret of this immaturity (Benjamin, [1921] 1996).

In order to understand the nature and ways of this final revelation of God, it is necessary to understand why, according Benjamin, Nietzsche's superman marks the "beginning" of the fulfilment of the religion of capitalism:

The idea of the superman transposes the apocalyptic "leap" not into conversion, atonement, purification, and penance, but into an apparently steady, though in the final analysis explosive and discontinuous intensification. For this reason, intensification and development in the sense of non facit saltum are incompatible... The superman is the man who has arrived where he is without turn (Umkehr); he is historical man who has grown up right through the sky. This breaking open of the heavens by an intensified humanity that was and is characterized (even for Nietzsche himself) by guilt in a religious sense was anticipated by Nietzsche... (Benjamin, 1921] 1996).

The "leap" is made in absolute solitude by the one who becomes a "creator":

Would you go into isolation, my brother? [...] You lonesome one, you go the way of the creating one: a God will you create for yourself out of your seven devils! (Nietzsche, [1885] 2010, I, 17: 54-55). 
The creator creates the new, the old man wants the old:

The new, would the noble man create, and a new virtue. The old, wants the good man, and that the old should be conserved (Nietzsche, [1885] 2010, I, 8: 39).

Creating - that is the great salvation from suffering, and life's alleviation. But for the creator to appear, suffering itself is needed, and much transformation.

Yes, much bitter dying must there be in your life, you creators! Thus are you advocates and justifiers of all perishableness.

For the creator himself to be the new-born child, he must also be willing to be the child-bearer, and endure the pangs of the child-bearer.

Truly, through a hundred souls went I my way, and through a hundred cradles and birth-throes. Many a farewell have I taken; I know the heart-breaking last hours.

But so wills it my creating Will, my fate. Or, to tell you it more candidly: just such a fate - wills my Will.

All feeling suffers in me, and is in prison: but my willing ever comes tome as my emancipator and comforter.

Willing emancipates: that is the true doctrine of will and emancipation - so teaches you Zarathustra.

No longer willing, and no longer valuing, and no longer creating! Ah, that that great debility may ever be far from me!

And also in discerning do I feel only my will's procreating and evolving delight; and if there be innocence in my knowledge, it is be- cause there is will to procreation in it. (Nietzsche [1885] 2010, II, 2, pp. 70-71)

The "leap" also applies to the concepts of law and justice. Nietzsche had criticized and rejected the old concept of justice as fairness already in The Genealogy of Morals:

The active man, the attacking, aggressive man, is always a hundred degrees nearer to justice than the man who merely reacts... has at all times enjoyed the stronger, bolder, more aristocratic, and also freer outlook, the better conscience (Nietzsche, [1887]: 63)

The juridical form of justice evolves and ends with "grace", ultimately destroying itself:

Grace! It remains, as is obvious, the privilege of the strongest, better still, its being beyond the right (Nietzsche, [1887]: 63).

This justice doesn't follow any laws or rules. It is beyond and above them, because every rule is limited, as is its purpose. To have a purpose limits life's power. In Thus Spoke Zarathustra, life itself claims that every new created situation becomes an obstacle, an enemy of creation, and therefore has to be destroyed:

And this secret spoke Life herself to me. "Behold," said she, "I am that which must ever surpass itself.

Whatever I create, and however much I love it, - soon must I be adverse to it, and to my love: so wills my will... he who has to be a creator in good and evil - truly, he has first to be a destroyer, and break values in pieces. (Nietzsche, [1885] 2010, II, 12: 93-94).

The superman's creation serves no purpose. Construction and destruction are the same thing. Coherently, Nietzsche rejects the principle of contradiction. Life - and with it the superman - affirms: 
I have to be struggle, and becoming, and purpose, and contradiction of the purpose (der Zwecke Widerspruch) [...] (Nietzsche, [1885] 2010, II, 12: 93-94).

In a late note Nietzsche writes:

The ways of freedom

Justice (Gerechtigkeit) as a constructive, exclusive, destructive way of thinking, that moves from judgments of value: highest representative of Life itself (Nietzsche, [1884-1885] 1988, VII, II)

\section{The will as judgment and revenge}

In his early text Philosophy in the Tragic Age of the Greeks, Nietzsche ([1870-1873] 1962) thought he could find the same concept of "pure" justice (dike) in Heraclitus: the necessary, reciprocal implication of conflicting contraries. According to Heraclitus, justice is strife (dike= eris, Heraclitus, Snell B 80). Nietzsche's metaphysic of creativity has some features in common with ancient pre-Socratic Greek philosophy. However, a concept such as that of the superman is totally foreign to Greek thought. Greek heroes were mediators between gods and men. Neither gods nor mortals were masters of time and of the world. According to Heraclitus, conflict (polemos) governs everything, according to strife and necessity (kat'erin kai kreomena). No mortal can govern conflict (Heraclitus, Snell B 62; B 80). Differently, Nietzsche claims that the superman can rule it. There is no eternal law that could prevent his control. The will can govern even the past!

That time does not run backward - that is its animosity: "That which was": so is the stone which it cannot roll called (Nietzsche, [1885] 2010: 113)

This distress of the will produces its animosity and revenge - that is, the source of all revenge. The lying conscience need to justify itself, so it calls the revenge "penalty":

The spirit of revenge: my friends, that has thus far been man's best contemplation; and where there was suffering, it was claimed there was always penalty.

"Penalty," so calls itself revenge. With a lying word it feigns a good conscience. (Nietzsche, [1885] 2010: 113)

Human madness came up with the notion that revenge and penalty must affect everything:

"Everything perishes, therefore everything deserves to perish!"

And this itself is justice (Gerechtigkeit), the law of time - that he must devour his children:" thus did madness preach.ss:pi" Morally are things ordered according to justice and penalty. Oh, where is there deliverance from the flux of things and from the 'existence' of penalty?" Thus did madness preach. (Nietzsche, [1885] 2010: 114)

Nietzsche seems to be referring to the fragment by Anaximander (Diels 1903, A 9), or to the old satyr Silenus, who, when asked by King Midas what the best thing for humans might be, answered that the best thing would be to never have been born, but, since one has been born, that it is to die as soon as possible (Nietzsche, [1872] 1923, § 3). However, I think that there is also a hidden reference to Christian Medieval theology. Zarathustra continues:

"Can there be deliverance when there is eternal justice (ewiges Recht)? Alas, unrollable is the stone, 'It was': eternal must also be all penalties!" Thus did madness preach.

"No deed can be annihilated: how could it be undone by the penalty! This, this is what is eternal in the 'existence' of penalty, that existence also must be eternally 
recurring deed and guilt!" (Nietzsche, [1885] 2010: 114).

Early Medieval Christian theology maintained this condemnation of life, inherited from ancient religions and philosophies and disguised as original sin: earthly life has no redemption from death. Only God can redeem life from death since he is the creator, but even he cannot change the past - including original sin.

Unless the Will should at last deliver itself, and Willing become non-Willing-: "but you know, my brothers, this fabulous song of madness! (Nietzsche, [1885] 2010: 114).

Nietzsche considers the solution given by Schopenhauer and his kind of 'Buddhism', and rejects it.

Away from those fabulous songs did I lead you when I taught you: "The Will is a creator".

All "It was" is a fragment, a riddle, a fearful chance - until the creating Will says to it: "But thus would I have it."

Until the creating Will says to it: "But thus do I will it! Thus shall I will it!" (Nietzsche, [1885] 2010: 114).

If I will what was, my past is not separated from my present: it is my will, or better: the will. Past and present are the same life that is a unique changing phenomenon in which destruction and creation are the two facets of the same thing. That is "active" nihilism. This thought is not absolutely new. We can find similar thoughts in Hölderlin (whose work Nietzsche knew and appreciated), in Hegel and in Goethe. Moreover, the acceptance of the "event" was the core of Stoic philosophy. The acknowledgement of impermanence is the core of true Buddhism. What Nietzsche rejects in Schopenhauer's Buddhism is resignation, but this does not have much to do with genuine Buddhism. If what is at stake were the peaceful or even joyful recognition of what happens - without any spirit of revenge Nietzsche's thought would agree with Buddhism or even with some aspects of Greek Stoic or Epicurean philosophy. But what is at stake is something different: the ability to control - as "the active man, the attacking, aggressive man" does - the whole experience, through action. Zarathustra's language reveals this determination to become the master of life as "judge" and "avenger":

Terrible is aloneness with the judge and avenger of one's own law $[\ldots]$

Can you give to yourself your bad and your good, and set up your will as a law over you? Can you be judge for yourself, and avenger of your law? (Nietzsche, [1885] 2010: 54).

In Nietzsche there is no individual or collective existence in itself (as in the philosophy of Aristotle, for example). The will to power is not a spontaneous human attitude, but must be achieved through exercise, through askesis, through judgment governed by will, through a heroic decision that goes even against one's own creation, against what one loves:

$[\ldots]$ you love yourself, and on that account despise you yourself, as only the loving ones despise.

To create, desires the loving one, because he despises! What knows he of love who has not been obliged to despise just what he loved! (Nietzsche, [1885] 2010: 55) 
The superman frees himself from previous habits and preferences, from heteronymous judgments, but not from the duty to constantly pass judgment on the present situation and on himself. Nietzsche does not acknowledge that most human desires and fears are natural aspects of life. Instead, I believe that they cannot be ignored or destroyed by means of an act of will (a sort of "revenge", as Nietzsche himself puts it): this kind of direct opposition only increases their importance by creating an irresolvable inner conflict. It is better to give those desires and fears enough time to reveal their essence, so that they may even be deactivated, by making them less urgent by comparison with the immeasurable greatness of life. Nietzsche's love of life is unilateral: it is love of the will and of power over life, rather than love of life with all its complex shades, including sympathy, sorrow and compassion. He needs to measure his will as the power against these feelings. The will and actions of the superman constitute an exception to these feelings and their corresponding habits, but in a certain way still depend on them. The superman needs the under-men - and needs to be continuously surpassed and recreated. This differentiation is the "leap", the "discontinuous intensification" in this process of "growing up right through the sky" "with no turning back" (ohne Umkehr).

In The Genealogy of Morals Nietzsche states that Kant's moral law stinks of cruelty. Nietzsche's law seems just as cruel. However, for the superman terror and joy mix together in a Dionysiac thrill (see already The Birth of Tragedy, $\S 1$ ). This is the new, unprecedented, infinite freedom (see The Joyful Wisdom, § 124) and enjoyment of Life (subjective genitive) promised by the superman.

\section{Creativity: a political-theological knot}

Benjamin's references to Nietzsche are essential to understand why this text on capitalism as religion is so prophetic about the new capitalism, especially with reference to the use of the concept of creativity. I should recall that this concept - not mentioned in Benjamin's text - was later explicitly criticized in The Artwork in the Age of Mechanical Reproduction: creativity is - together with the 'aura' of geniality, uniqueness, and the hic and nunc - a fundamental attribute of the quasi-religious Fascist cults, which produce an "aestheticization of politics". Religion has become art, art has become aesthetic, the aesthetic dimension has become political. Nietzsche played a central role in the development of art beyond art, as the power of strengthening life:

Man is no longer an artist, he has become a work of art (Nietzsche, [1872] 1923, §1).

Now, let us briefly consider some genealogical features of the contemporary use of the concept of "creativity". Its genealogy is very complex. One element goes back to the Christian theology of creation. Nowadays, the concept may suggest the renewal of life, freed from the burden of evil and suffering. Indeed, this is meaning is essential to the early Christian message, but it has to do with the purification of life and not with creation, which belongs only to God. The superimposition of the concepts of redemption and creation is due to a late modern trend towards a tight reciprocal implication - almost identification between human existence and religious experience. 
This reciprocal implication has one of its preconditions in late medieval Scholastics, where (Ockham) God was conceived as free creating will, without purposes understandable to humans. In a way, Ockham anticipated Nietzsche - indeed in a more realistic sense attributing to God a will and a power beyond every law, and capable even of changing the past. Thus, the separation between God and humankind became huge, especially after the breakdown of the unity of Western Christendom from the Sixteenth century onwards. The philosophical existential "doubt" in Descartes (who had served as an officer in the Thirty Years' War) implied that God (re)creates the world at each moment (Descartes, Meditationes de prima philosophia, 3). A reaction to that separation was, later, the transfer of the burden of existence and decisions about good and evil onto human shoulders. Herein lie the seeds of the existential aspects of Nineteenth and Twentieth-century philosophy, literature and cinema. What also developed out of this anthropocentric turn is the shift of religious meanings into the domain of the arts, at the end of the Eighteenth century. Through the concepts of "genius" and "originality", what had hitherto been God's prerogative, namely creation, came to be attributed to human beings, if only partially so. The "genius" is original in so far as in his own person, by analogy with the Son of Trinitarian theology, he allows Nature (the Creator) to create new realities that do not follow any old rule (Kant 1790] 1983 $\S \S 46-47$ ). Artists acquired an intermediate role between Greek "heroes" (mediators between men and gods) and prophets.

At first, with Kant and Schiller, creativity was assigned to humans only in the aesthetic domain, but soon the theological principle of creation was turned into a logical (Hegel), cosmological (Hölderlin, Schelling) and anthropological (Novalis) one. Nietzsche identified art and life more radically. For Nietzsche, Art recognizes and produces the arousal that is necessary to enhance the power of life, the will to power. Nietzsche was to push this energetic physiological aesthetics to its very limits, by assigning tragedy the power to further life (Nietzsche, [1888] 1988, 14: 117, 119, 120). In doing so, Nietzsche expresses one aspect of the "parasitism" of Christian religion by capitalism.

In the same modern age, the religious organization of "salvation" shifted to the political and economic domain, as salvation from poverty, ignorance, etc. Art become 'political' thanks some avant-gardes the like the Futurists and the Surrealists; in turn, politics become artistic, or better, "aestheticized" in a spectacular manner, by the Fascists (Benjamin, [1935] 2012). The disastrous experiences of the mass wars of the Twentieth century reinforced existential feelings. Existential - even romantic - aspects became familiar to the masses and to individuals, through popular literature and films, and their characters: the "cowboy" in a lawless land, the detective who must transgress all laws and rules in the urban jungle, and even the criminal.

After World War II the Universal Declaration of Human Rights provided a reaction against all racial, ethnic and personal discrimination. All men have the same rights and nobody has the right to abuse others. Every individual's existence is unique and immeasurable: it is not a mere means for others. It has no price. This idea of irreplaceable uniqueness, in the shared way of thinking of post-Christian West, is the basis of the political principle of human rights. This principle is defended not so much because men have interests in common or because they are equal, but rather because everybody is different (see, nowadays, the UNESCO Convention on the Protection and Promotion of the Diversity of Cultural Expressions, 2005). Modern capitalistic economy engenders the belief that it is realizing this uniqueness, with an 
increasing radicalization of uniqueness by means of its continue, somehow 'Nietzschean' capability of differentiating each individual from the rest - and even from him/herself! (On the contrary, capitalism governs and standardizes the main means and forms of differentiation: each person appears as an individual on Facebook, while the form in which each person expresses him/herself - the 'message' (McLuhan [1964] 1991) - is the same for all). Is it surprising that this capitalistic creativity is prevailing over the democratic principle of fairness?

\section{Silk and gold, and the reverie of the new capitalism}

The features of current capitalism have different levels of depth and nearness to its hard core. The more superficial level is under the sign of entertainment. Movies, TV serials and video-games offer adventures challenging human limits on earth or in space. The surpassing of 'normal' human life is anticipated through images of hybrids, mutants, creatures between life and death, and vampires. Many artists (like Damien Hirst) play with the spectacularization of the borderline between horror, disgust, and curiosity. What matters is not whether it is clear that this is a game or even a joke, an odd exercise in humor; whether a 'morally correct' judgment is implicitly or explicitly given or not (for instance, in a videogame like Injustice). What is decisive is that the imagination of young people (or even people not so young) is trained to go beyond the old rules, beyond good and evil. Children and teenagers have to become rapid-changing, that is: apt to create\&destroy (even: to be destroyed). All this content is produced and distributed by the digital "creative industries", so that the circle feeds itself. At a superficial, yet extensively shared level, this is pleasant, amusing, and exciting. This is the level where

Beside thee is the ocean; it is true it does not always roar, and sometimes it spreads out like silk and gold and a gentle reverie [...] (Nietzsche, [1882] 1924, § 124).

This "silky" and "golden" trend doesn't concern only young people. Who wants to lead a boring, stagnant life? Who doesn't want to imagine and represent oneself as brave (and charming) enough to face the risks of the unexpected? Who doesn't wish to appear unique, original and irreplaceable by means of a personal style or a "creative" job, or even by violating the law and established morals? If existence is not ruled by an eternal law, the gesture that breaks down the suffocating circle of the always identically repeating days and years, is perceived to be the only one which makes one live, which lends meaning to an existence that, otherwise, would be lived as chance or destiny. But every gesture, once made, becomes dead. Thus, the uniqueness must be continuously repeated and recreated. The market comes to rescue! Advertising - this artificial and invasive 'reverie' - offers every new product as an unmissable 'emotion', regardless of the fact that these products - as in the case of cars - are all very similar except for some minor details. A repetitive, copious marketing literature praises "emotional marketing" (also in connection with neuroscience), "experiential marketing", even "existential marketing" (Gnasso and Iabichino, 2014), and the "experience economy": "Work Is Theater \& Every Business a Stage"! (Pine, Gilmore 1999). The new capitalism uses every kind of rhetoric and manipulation of feelings and emotions (Illouz, 2007; Metelmann and Beyes 2012), in order to make the consumer an accomplice (Toffler [1980] 1990; Kotler, Kartayaja and Setiawan, 2010; Peterson and Rossman, 2007) of the aestheticizing of economy and society (Reckwitz, 2013; Goldoni, 2013; 2015a). An evident 
propaganda aim, namely to flatter young unemployed or underemployed people and to trigger their engagement in the new economy, is to be found in this statement by the Green Paper Unlocking the CCI:

Everyone is creative in some way or another, and can learn to use his/her creative potential (10-11).

At the same time, a deep historical mutation of the nature of 'art' - well beyond anything accomplished by the avant-gardes - has taken place through the new capitalistic economy and its use of new technologies:

Access to and participation in the arts are constantly changing shape while the frontiers between creators and consumers are blurred with the development of participatory technologies such as blogs, wikis etc... Subcultures are emerging that result in a multidisciplinary mix of traditional and new artistic forms and content ... If Europe wants to stay at the cutting-edge, further interactions between different artistic and creative disciplines, (sub)sectors, economic fields and points in the production chain are needed.

The new economy is doing much more than the avant-gardes in order to transform art itself into everyday life - indeed: into a kind of everyday life dominated by the everyday cult of capitalistic religion.

\section{Towards a frightening revelation of this God?}

Beyond any attempt to reconstruct direct influences and genealogies (Backhaus and Drechsler, 2006), one can see how Nietzsche's theory of the superman describes and prescribes - beyond his purposes - some features of the behavioural rules and lifestyles required by so-called creative and financial capitalism. Money in its digital form knows no limits. The only rule is to make more money: this is intensification without changing direction, according Benjamin. Every contradiction in terms of purposes becomes possible. Indeed, contradictory purposes, within the overall context of production, may even be favorable to capitalism, because they can bring price fluctuations on the stock market, where financial speculation and the resourcefulness of new investors can take advantage of bankruptcy. Current capitalism flourishes through a constant process of innovationdestruction (Harvey, 2006). It realizes an idea theorized by Schumpeter (Schumpeter, 1942). And it also realizes the law of the superman, according Nietzsche:

That I have to be struggle, and becoming, and purpose, and contradiction of the purpose (der Zwecke Widerspruch)... (Nietzsche, [1885] 2010: 93-94)

Capitalism, like the justice of the superman, constitutes an exception. It is not subject to the law of repayment of debt. This debt is removed because it is assumed by banks; the banks' debt is assumed by states; and the states' debt falls on the shoulders of citizens. There is also a faster way to clear the debt: bankruptcy. Jurists, politicians, lawyers and functionaries are the officiating ministers of the worship of this exception. They are similar to Catholic priests, who, according the Council of Trent, can exercise their ministry and impart sacraments even when they are in mortal sin: the Spirit authorizes them.

This happens in periods and areas of 'peace'. The spectacularization of the economy, together with the internal police armed forces, maintain the order. However, when this kind of control doesn't work anymore, the armed police works in a super-national space. The capitalistic economy prepares and triggers turbulences and conflicts everywhere. There is an 
important part of this economy that amounts to low-intensity warfare, while actual warfare that has constantly been raging in the world since the Twentieth century - is always a fast economy.

When older forms of life - outside Western areas or within them - only react, because they have lost the ethics of their ancient ways of life, and respond by adopting the modes of life and the technical means of Western economy (as is now happening quite literally, since money, technologies and weapons mostly come from the West), there is no longer war, but armed terror. Terror is the greatest factor of disorganization in modern "disciplinary" societies (Deleuze, [1987] 1998). It allows power to exert all its "control" and its "right" in a "state of exception" (Agamben, 2005 ).

When KH. Stockhausen made the shocking claim that the destruction of the Twin Towers was the greatest work of art of the Twenty-first century, I believe that he was neither endorsing terrorism nor expressing appreciation of this action as an artwork. Rather, I suppose that he was trying to say - if only far too provocatively and without the necessary tact of at least waiting to clarify his thought - what art, or better - I would say - the spectacle of technical and economical power is becoming. Already Marinetti had predicted (and promoted) this connection between "art" and the spectacular explosion of armed violence in the Second Futurist Manifesto of 1936:

[...] War is beautiful because it establishes man's dominion over the subjugated machinery by means of gas masks, terrifying megaphones, flame throwers, and small tanks. War is beautiful because it initiates the dreamt-of metallization of the human body. War is beautiful because it enriches a flowering meadow with the fiery orchids of machine guns. War is beautiful because it combines the gunfire, the cannonades, the cease-fire, the scents, and the stench of putrefaction into a symphony. War is beautiful because it creates new architecture, like that of the big tanks, the geometrical formation flights, the smoke spirals from burning villages, and many others ... Poets and artists of Futurism! [...] remember these principles of an aesthetics of war so that your struggle for a new literature and a new graphic art [...] may be illumined by them!

This spectacle is essential to the religion of capitalism. And it is broadcast everyday, from every part of the world. It is the culminating point of the celebration of the reciprocal transubstantiation between the economy and violence.

Its fourth feature is that its God must be hidden from it and may be addressed only when his guilt is at its zenith. The cult is celebrated before a immature deity; every idea, every conception of it offends against the secret of this immaturity (Benjamin, [1921] 1991).

The God of this religion manifested himself horribly between 1933 and 1945. While he still seems immature and hidden at the beginning of the Twenty-first century, is he taking strides towards an even greater revelation?

\section{Weak attempts at resistance}

The fascinating power of the "creativity" apparatus crosses the boundaries between the political left and right. What I have in mind here is not just the LibLab, which in the UK, in the Nineties, used this concept as a political-cultural flag (Goldoni, 2015a). I am also thinking 
of certain radical philosophers. For instance, let us read an extract from a 1977 interview with Gilles Déleuze, against "le nouveaux philosophes":

Rencontrer avec son propre travail le travail des musiciens, des peintres ou des savants est la seule combinaison actuelle qui ne se ramène ni aux vieilles écoles ni à un néo-marketing. Ce sont ces points singuliers qui constituent des foyers de création, des fonctions créatrices indépendantes de la fonction-auteur, détachées de la' fonction-auteur... Eh bien, chaque fois que les fonctions créatrices désertent ainsi la fonction-auteur, on voit celle-ci se réfugier dans un nouveau conformisme de «promotion». C'est toute une série de batailles plus ou moins visibles : le cinéma, la radio, la télé sont la possibilité de fonctions créatrices qui ont destitué l'Auteur ; mais la fonction-auteur se reconstitue à l'abri des usages conformistes de ces médias. Les grandes sociétés de production se remettent à favoriser un «cinéma d'auteur» ; JeanLuc Godard trouve alors le moyen de faire passer de la création dans la télé ; mais la puissante organisation de la télé a elle-même ses fonctions-auteur par lesquelles elle empêche la création. Quand la littérature, la musique, etc., conquièrent de nouveaux domaines de création, la fonction-auteur se reconstitue dans le journalisme, qui va étouffer ses propres fonctions créatrices et celles de la littérature. Nous retombons sur les nouveaux philosophes : ils ont reconstitué une pièce étouffante, asphyxiante, là où un peu d'air passait. C'est la négation de toute politique, et de toute expérimentation (Deleuze, 1977).

The polemical target is very well chosen. The reasoning is clear. On the one side, there is life as "creation" (mentioned eight times in fourteen lines of text). On the other side, there is the private property of the "author", imprisoning and suffocating life. Deleuze was fighting against an older form of capitalistic and industrial power: against the division of labour between producer (author) and consumer (reader, viewer, listener...), against private intellectual property. This reasoning, in 1977, was no so far from the Marxist perspective of freeing the productive energies of life. He intensified and surpassed orthodox Marxism also with the help of Nietzsche. While orthodox Marxism thinks of economic production as a "structure", Deleuze conceived production as creativity without limits. Nowadays capitalism submits creativity to profit in a way that transcends the traditional, static and professionally stable division of labor. Intellectual private property is under attack from digital technologies. Nor is its defence in the interest of those who wish to invest money by exploiting the inventions that can be found on the Net. Creativity grows - and capital with it - with the full cooperation between Internet users and producers. Artists are seen as sources of creativity.

A more intensive, systematic, and wide-ranging collaboration between the arts, academic and scientific institutions should be promoted, as well as private-public initiatives to support artist-led experimentation [...] As a rule, CCIs build upon a rich and diverse core of cultural heritage and skilled artists and other creative practitioners and rely on the effective interconnection of various related layers of entrepreneurial and innovative services to bring creativity to the market... (Green Paper Unlocking the CCI).

Capitalism is realizing suggestions given by artists (like Joseph Beuys) and political critics in the Sixties and Seventies (Boltanski-Capiello, 2005; Reckwitz, 2013). In a lecture delivered on the 17th of March 1987, Gilles Deleuze (Deleuze, [1987] 1998) voiced his awareness of this change. He did not even wish to speak of "art" but of an "act of resistance": 
There is no work of art which is not addressed to a people that does not yet exist!

He agreed with Foucault, which in 1978 denounced the rise of "biopolitics" (Foucault, [1978-1979] 2004). After the societies of "sovereignty" and "disciplinarity", the current one was described as a society of "control". Control does not need disciplinarity. It doesn't consist in the surveillance of activities in order to make them serve a given purpose. A consistency of purposes is not necessary. Control becomes effective by letting people produce "data" available to power. It works better by giving means of freedom - like highways (to take Deleuze's example): people are free to go wherever they want but, at the same time, they are perfectly under control. Nowadays, cell phones and the Internet are even more suitable examples.

The lecture was filmed and broadcast by FR3 with the title Qu'est-ce que l'acte de création? Even in Portrait du philosophe en spectateur (Deleuze, 1983) and Le cerveau, c'est l'écran (Deleuze, 1986), new against old and creativity against imitation remained Deleuze's paradigm concepts. So, he still followed Kant's concept of genius (Kant 1990, §§ 46-47). Almost prophetically, in Le cerveau, c'est l'écran he claimed: "perhaps the cinema is still not capitalistic enough!" I wonder: is the concept of "creation" adequate to describe and suggest lifestyles capable of resisting the society of control? I am not arguing that every meaning of the word "creativity" is under the sign of capitalism. Nor am I denying the possibility to use this word with the best intentions, or to detect philosophical meanings within it that go in other directions, like, e.g., the ability to transform an obstacle into an opportunity, or to free own imagination and desires by stereotypes - but this corresponds to a subjective feeling of freedom: if we look at the influences of technologies and economy on the desires and the imagination, the meaning of the word "freedom" pales. In the present text I do not wish to get into a broad discussion about the philosophical literature on this concept (all too often techniques of philosophical argumentation can make a word mean both one thing and its opposite), although some time ago I did offer some criticism of a philosphical book by $\mathrm{E}$. Garroni, with a preface by P. Virno (Garroni [1978] 2010) - and I have no reason to change my mind (Goldoni 2013: 21). Now I am more interested in considering to the use of this word in economic, political and common language contexts. When a word is used in such a widespread way, it is interesting to take a close look at the ambiguities of its uses. Many interesting things can be done - and are done - in the name of creativity. But many bad things, too, are done in its name: the exploitation of workers, and even self-exploitation; the wasting of money to let archistars build unnecessary monuments in so-called "creative cities" in every part of the world, from Europe (e.g. the MAXXI in Rome) to China (e.g. the "creative quarters" in Chen-Zhen) (Goldoni, 2013; 2015a).

I am interested in interpreting the emergence of "creativity" as the symptom of a deep change in Western forms of life (Goldoni, 2015b). Traditional energy sources (e.g. oil, uranium) are running out. Economic growth has shown its limits. A struggle is underway to decide how to live in the near future. "Immaterial" human creativity seems to be an unlimited resource for production. Thus, it appears that the struggle revolves around the issue of whether creativity has to be governed by the few or whether the multitudes can use creativity to free life for its own sake. However, I think that there is a 'reason' why the principal, dominant use of "creativity" is the capitalistic one. The notion of creativity - as it is conceived and applied in its ordinary sense - has the same ontological core as the Christian theology of salvation and the religion of capitalism: the concept of life as a production and demonstration under a higher judgment. All "creativity" implies the display of its own 
unfolding or results to a public (be it internal or external), which is the judge. Thus, it offers itself to control.

It is not surprising, therefore, that those forms of opposition to capitalism which have radicalized some aspects of Marx's theory, while still standing in continuity with its productivistic horizon, are fascinated by the idea of creativity. Benjamin observed:

This breaking open of the heavens by an intensified humanity that was and is characterized (even for Nietzsche himself) by guilt in a religious sense was anticipated by Nietzsche. Marx is a similar case: the capitalism that refuses to change course becomes socialism by means of the simple and compound interest that are functions of Schuld [...] (Benjamin, [1921] 1991).

The political weakness of the opposition movements of the late Seventies - as, perhaps, of the ones that fight for a freer form of creativity - seems to be a philosophical weakness.

\section{Deactivating creativity: for a politics of friendship}

The power of the myth of creativity also consists in the fact that it shares with the philosophical truth the acknowledgment of the singularity of human life. The myth works because it is so close to the truth - in a mimetic form - that it conceals it. The greater its strength, the weaker the capability to think and live natural human uniqueness outside of capitalism. The void left by the lack of acknowledgment of natural uniqueness must be unceasingly filled by action. Action must destroy the past, void the present existence and start from scratch every time, in order to deserve its own life. The economic debt corresponds to the debt that each one has with his/her own existence. But existence does not need to be deserved, or justified, or augmented. Aristotle identifies happiness with the purest $\alpha v \tau \alpha \varrho \kappa \varepsilon\llcorner\alpha$ (energheia) of life. He says that awakening, perceiving and thinking are sweet in themselves, and that the pleasure of God is of the same nature, though more perfect, because it is always so, while for us it is so only at certain times:

And his pleasure is this energheia (and thanks to it, awakening, perceiving, thinking are very pleasant, and hopes and memories through these) (Aristotle, Metaphysica XII 1072: 16-18).

What unites awakening and perceiving with thought and imagination is a state of awareness of one's own existence and of harmonic consent to it. In the Greek word energheia all these aspects coexist in the awareness of existence as energy. The translation of this word is difficult in those languages in which culture has led to a separation between perception and thought, between possibility and reality, in which culture has ended up giving the word "energy" a physical-mechanical meaning. The point made in Metaphysics XII is confirmed by a passage of the Nicomachean Ethics. Here Aristotle talks about the sweetness of living and of the awareness of such pleasure.

[...] if living is good and sweet in itself ... and in seeing we perceive that we see and in hearing that we hear and in walking that we walk, and in the other cases similarly there is the perception that we are exercising this awareness of them (ot $i$ energoumen), so that, if we perceive, we perceive that we perceive, and if we think, that we think; and if to perceive that we perceive or think is to perceive that we exist 
(for existence was defined as perceiving or thinking); and if perceiving that one lives is in itself one of the things that are pleasant [...] (Aristotle, Ethica Nicomacaea 1170 a $17 \mathrm{ff})^{2}$.

Aristotle speaks here of a joy of existence that does not depend on special qualities of life. Later, Rousseau was to recall this awareness:

Of what are we happy in this situation? Of anything external to oneself, nothing else but of oneself and his own life; as long as this state lasts, each one is sufficient to oneself as God. The feeling of existence, stripped of any other affection, is itself a precious feeling of contentment and peace [...] (Rousseau, [1782] 1959: 1047) .

Life is good in itself, even in its singularity, for each person. There is no judgment. In its simple, incomparable nature, individual existence cannot be created, increased or decreased. It cannot be due. It can only be appreciated, loved, celebrated or despised, offended, and destroyed. Concepts such as "creativity", "originality" and "talent" belong to a historical trend of civilization according which life should be continuously recreated and increased. They stand at the opposite side of the poetic voice, which, in every art, philosophy or way of life, commands attention through its emergence from an involuntary memory. No one knows how and why some memories remain etched in our mind and then emerge, even after some time, so insistently; why - when we are given to choose, in the arts as in life - it is just a few memories that one is willing to bring up, while others pass away without leaving any trace; why one is willing to care for them, to cultivate them (for it is only subsequently that one may be motivated to search for the "reason" for his/her 'choice'). No one knows how and why each person (immediately) knows when life is celebrated or is offended. Something touches our desire in the point where the 'possible' in life urges us, but does not yet find expression. Attention (the 'new') is captured where there is work on oneself. The 'new' that touches our desire is what removes a burden (in this sense, the 'new' can also be obtained by means of a simple, already existing, not new, material: as in some of the works by John Cage, Pauline Oliveros and Rauschenberg). The 'new' is in the process of awareness, which activates the energy of life. Work on oneself is an ongoing process that approaches the essence. The unexpected, sudden, "original" is life itself, when it appears in its uniqueness, free from any duty or judgment or merit.

Full of merit, man nonetheless poetically inhabits this earth (Hölderlin [1807?] $1992)^{4}$.

It does not appear "in" the time of the processes of production, nor in those of so-called creativity.

Poets, musicians, philosophers and ordinary people do not speak out of a desire for originality, but under the 'dictation' of life. Their voice has been found, invented (inventio):

E quanto all'originalità vera, essa risiede naturalmente un po' più nel profondo che nei toni accidentali di una personalità tipica. Sarà perché di questo si è abusato in questi cinquant'anni, sarà perché nel senso dell'espressione tipica individuale si è esasperato il talento di alcune generazioni, che oggi l'originalità così intesa è la cosa meno originale del mondo. E dire che in cima ai pensieri del poeta sta evidentemente come un miraggio o un'allucinazione un'opera che appaia come una

\footnotetext{
2 my translation

${ }^{3}$ my translation

${ }^{4}$ my translation
} 
pura determinazione, un'operazione logica o, se volete, matematica inevitabile e che possa sembrare fatta da chiunque altro e anzi, per meglio dire, neppure fatta, ma esistente in natura (Luzi, 1964: 41).

This voice is naturally unique, as is the existence of each person. This - if you like - is true originality: the voice that answers the call of its origin - nature - that no one can control. It seems to me that this is even close to what Emerson means, although he uses the equivocal, subjectivistic and, at the same time, universalistic concept of "genius":

To believe that what is true for you - just for you - is true for all men, this is the genius. Give voice to the latent belief in you and it will acquire a universal meaning [...] (Emerson, 1841: 1).

I would say, rather: not universals, but new consonances may arise, without obligation or judgment.

This does justice to life. Knowing this does not ensure any 'rights' in itself, but gives one the power to bring an end to the circle of guilt and debt, the compulsion to be acknowledged and approved. This freedom can be exercised, and hopefully shared, in many different moments and situations, by deactivating the compulsion to be creative. To free oneself is the necessary condition for free relationships of friendship. The shared acknowledgement of this liberation is what lends such relationships a political value and dimension. A deeper justice may emerge.

\section{Conclusion}

The so-called knowledge-based capitalism engenders the belief that it promotes the development of individual life, by means of its (somewhat 'Nietzschean') creation of the new, based on the destruction of old lifestyles and rules. Even though capitalism actually standardizes the means (media) of self-expression and individual lifestyles from time to time, in order implement its unchangeable rule of profit, the spectacle of relentless creativity remains essential to the current religion of capitalism. This spectacle is broadcast everyday in different domains and with different faces and names (economy, politics, arts, warfare) as the celebration of the cult of the reciprocal transubstantiation between the economy and violence.

In the Seventies, some forms of opposition to capitalism showed a fascination with the idea of creativity. But all creativity implies the display of its own unfolding or results: thus it offers itself to control. This is one of the reasons for the weakness of those opposition movements. True resistance does not obey the imperative to participate in the spectacle of creativity. True resistance deactivates this spectacle in order to do deep justice to natural life.

\section{Keywords}

Debt; religion; creation; destruction; justice. 


\section{Reference list}

Adorno, Th. W. (1998) [1947] "Kultur Industrie. Aufklärung als Massenbetrug", in Horkheimer M., Adorno Th. (1947), Dialektik der Aufklärung, in Adorno Th. W. (1998) Gesammelten Schriften, vol. 3: 141 -191. Darmstadt: Wissenschaftliche Buchgesellschaft.

Agamben, G. (1995) Homo sacer: Sovereign Power and Bare Life, Redwood City: Stanford University Press.

Agamben, G. (2005) State of Exception, Chicago: University of Chicago Press.

Agamben, G. (2011) The Kingdom and the Glory. For a Theological Genealogy of Economy and Government, Redwood City: Stanford University Press.

Agamben, G. (2013) "Il capitalismo come religion”, in Agamben, G., Archeologia dell'opera, Mendrisio: Mendrisio Academy Press.

Aristotle, Metaphysics, ed. W. Jaeger (1980), Oxford: Oxford University Press.

Aristotle, Ethica Nicomachea, ed L. Bywater (1984), Oxford: Oxford University Press.

Backhaus, J.G., Drechsler, W. (eds) (2006) Friedrich Nietzsche (1844-1900). Economy and Society, New York-Berlin: Springer.

Benjamin, W. (1991) [1921] "Kapitalismus als Religion", in W. Benjamin, Fragmente. Autobiographische Schriften. Gesammelte Schriften. pp. 100-103 Vol VI, Frankfurt a. M. 1991: Suhrkamp.

Benjamin, W. (1996) [1921] "Capitalism as Religion", in Selected Writings Vol.1, (Belknap Harvard Press, 1921, 1996) pp. 288-291. Translated by Rodney Livingstone. Posted 3rd March 2014 by Brotherwise Dispatch Editorial Cipher.

Benjamin, W. ([1935] 2012) “Das Kunstwerk im Zeitalter seiner technischen Reproduzierbarkeit", Fünfte Fassung, in W. Benjamin, Werke und Nachlass, Kritische Gesamtausgabe, Berlin: Suhrkamp.

Boltanski, L., Chiapello, E. (2005) The New Spirit of Capitalism, London: Verso.

Débord, G., (1967) La Societé du Spectacle, Paris 1992: Gallimard.

Deleuze, G. (1977) “Les “nouveaux philosophes"”, Supplément au n²4, mai 1977, de Minuit. http://www.generation-online.org/p/fpdeleuze9.htm. Accessed on $7^{\text {th }}$ May, 2017.

Deleuze, G. (1983) "Portrait du philosophe en spectateur", In "Le Monde" the $6^{\text {th }}$ of october 1983.

Deleuze, G. (1986) “Le cerveau, c'est l'écran”, In Chaiers du cinéma n. 380.

Deleuze, G. (1998) [1987] “Qu'est-ce que l'acte de création?", Conference broadcast by FR3 the $18^{\text {th }}$ of may 1989; published in Trafic n. 27 (autumn 1998).

Diels, H. (1903) Die Fragmente der Vorsokratiker, Berlin.

Emerson, R.W. (1841) Self-Reliance, from Essay: First Series. http://www.emersoncentral.com/selfreliance.htm Accessed on $7^{\text {th }}$ May, 2017.

Florida, R. (2011) The Rise of the Creative Class. Revisited. New York: Basic Books. 
Foucault, M. (2004) [1978-1979] Naissance de la Biopolitique. Cours au Collége de France 19781979. Paris: Gallimard.

Fumagalli, A. (2007) Bioeconomia e capitalismo cognitivo. Verso un nuovo paradigma di accumulazione, Roma: Carocci.

Garroni, E. (2010) [1978] Creatività, Macerata: Quodlibet.

Gnasso, S.; Iabichino, P. (2014) Existential marketing: I consumatori comprano, gli individui scelgono, Milano: Hoepli.

Goldoni, D. (2013) “Estetizzazione dell'economia”, In P. D’Angelo, E. Franzini, G. Lombardo, S. Tedesco (eds) Costellazioni estetiche. pp. 206 - 215 Milano: Guerini \& Associati.

Goldoni, D. (2015a) "A musical-philosophical approach to creativity and the economy", In A. Cusinato, A. Philoppopoulos-Mihalopoulos (eds) Knowledge-creating Milieus in Europe: Firms, Cities, Territories. Berlin: Springer.

Goldoni, D. (2015b) “Cultural Mutation. What Media do to Culture”, in L. Zagato, M. Vecco, (2015), Citizens of Europe, Cultures and Rights, Venice: Ca' Foscari University Press.

Green Paper (2010) Unlocking the potential of cultural and creative industries. European Commission. Available

on: http://europa.eu/legislation_summaries/culture/cu0006_en.htm Accessed on $7^{\text {th }}$ May, 2017.

Hamacher, W. (2003) “Schuldgeschichte: Benjamin's Skizze 'Kapitalismus als Religon'”, In Baecker Dirk (ed) Kapitalismus als Religion, Berlin: Kadmos.

Harvey, D. (2006) “Neo-liberalism as creative destruction”, Geogr. Ann., 88 B (2): 145-158.

Hesmondhalgh, D. (2013) Cultural Industries, Los Angeles: Sage.

Hölderlin, F. (1992) [1807?] “In lieblicher Bläue...", In F. Hölderlin, Sämmtliche Werke und Briefe (Knaupp, M., ed), Munchen: Hanser; vol. I. p. 908 ff.. See also vol. III p. 354.

Illouz, E. (2007) Cold Intimacies. The Making of the Emotional Capitalism, Cambridge: Polity Press.

Kant, I., ([1790] 1983) Kritik der Urteilskraft, in Werke in Zehn Bänden, Darmstadt: Wissenschaftliche Buchgesellschaft, vol. 8: $233 \mathrm{ff}$.

Kotler, P., Kartayaja, H., Setiawan, I., (2010) Marketing 3.0: From Products to Customers to the Human Spirit, New Jersey: Wiley.

Lazzarato, M. (2011) La fabrique de l'homme endetté. Essai sur la condition néolibrale, Paris: Editions Amsterdam.

Legrenzi, P., (2005) Creatività e innovazione, il Mulino, Bologna 2005.

Löwy, M. (2006) “Le capitalisme comme religion: Walter Benjamin et Max Weber”, in Raisons politiques 23.

Luzi, M. (1964) L'inferno e il limbo, Il Saggiatore: Milano.

McLuhan, M. (1991) [1964] Understanding Media: the Extensions of Man. Massachusetts: Institute of Technology Press.

Metelmannn, J., Beyes, T. (2012) Die Macht der Gefühle. Emotionen in Management, Organisation und Kultur. Berlin: Berlin University Press. 
Mill, J. S. (2010) [1848] Principles of Political Economy. Whitefish MO: Kessinger Legacy Reprints.

Nietzsche, F. (1962) [1870-1873] Philosophy in the Tragic Age of the Greeks. Section 5. Translated by Marianne Cowan from Die Philosophie im tragischen Zeitalter der Griechen. Washington, D.C.: Regnery Gateway Inc.

Nietzsche, F. (1923) [1872] The Birth of Tragedy, in Levy Oscar (ed), The complete Works of Friedrich Nietzsche, vol. 1. Translated by Common, Thomas. New York: The MacMillan Company.

Nietzsche, F. (1924) [1882] The Joyful Wisdom, in Levy Oscar (ed), The complete Works of Friedrich Nietzsche, translated by Common, Thomas. New York: The MacMillan Company.

Nietzsche, F. (2010) [1885] Thus Spoke Zarathustra; ed. Chapko, Bill, Feedbooks,

Nietzsche, F. (1923) [1887] The Genealogy of Morals, translated by Horace B. Samuel. New York: Boni and Liveright Publishers.

Nietzsche, F. (1988) [1884-1885] Nachgelassene Fragmente 1884-1885, Kritische Studienausgabe; herausgegeben von Giorgio Colli und Mazzino Montinari, Berlin, New York: De Gruyter.

Nietzsche, F. (1988) [1888] Nachgelassene Fragmente 1888-1889, Kritische Studienausgabe, eds Giorgio Colli und Mazzino Montinari, Berlin; New York: De Gruyter.

Peterson, R.A., Rossman, G., (2007) “Changing arts audiences: capitalizing on omnivorouness", in B. Ivey, S. Tepper (eds), Engaging Art: The Next Great Transformation of America's Cultural life, New York: Routledge.

Pine B.J., Gilmore, J. H. (1999) The Experience Economy: Work Is Theater \& Every Business a Stage. Harvard: Harvard Business School.

Reckwitz, A. (2013) Die Erfindung der Kreativität: Zum Prozess gesellschäftliche Ästetisierung. Dritte Auflage, Berlin: Suhrkamp.

Rousseau, J.J. (1959) [1782] Les rêveries du promeneur solitaire. I, Oeuvres complètes. Paris: Gallimard.

Salzani, C. (2013) "Politica profana, o dell'attualità di 'Capitalismo come religione'”. "Introduzione", In Benjamin ([1921] 1991), Fragmente. Autobiographische Schriften. Gesammelte Schriften. pp. 7-37. Frankfurt a. M. 1991: Suhrkamp.

Schumpeter, J.A., (1942) Capitalism, Socialism and Democracy, New York and London: Harper \& Brothers.

Steiner, U. (2006) "Kapitalismus als Religion”, In Benjamin-Handbuch, B. Lindner (ed.), pp. 167-174 Stuttgart, Metzler.

Steiner, U. (1998) “Kapitalismus als Religion. Anmerkungen zu einem Fragment von Walter Benjamin", In Deutsche Vierteljahrsschrift für Literaturwissenscahft und Geistesgeschichte 72. I.

Stimilli, E. (2011) Il debito del vivente. Ascesi e capitalismo. Macerata: Quodlibet.

Stimilli, E. (2015) Debito e colpa, Roma: Ediesse.

Toffler, Alvin (1990) [1980] The Third Wave. New York: Bantam Books. 
UNESCO (2005) Convention on the Protection and Promotion of the Diversity of Cultural Expressions.

Virno, P. (2010) “Prefazione”, In Creatività (1978), E. Garroni, Macerata: Quodlibet.

Weber, M. (2014) [1905] The Protestant Ethic and the Spirit of Capitalism. Stellar Editions. 